\title{
Effects of mixed modes on fermentation quality and In vitro gas dynamics of sorghum-sudangrass hybrid (Sorghum bicolor $\times S$. sudanense) silage
}

\section{Efeitos de modos mistos para a qualidade de fermentação de silagem de sorgo-sudangrass (Sorghum bicolor $\times$ S. sudanense) e características de produção de gás in vitro}

\author{
Huan Liang ${ }^{1}$; Jinghua Zhang'; Guibo Liu ${ }^{3}$; Yuan Li $^{3}$; Yongliang You $^{3}$; Haiming \\ Zhao $^{3}$; Yemei Yang ${ }^{4}$; Yan Fan ${ }^{4}$; Jian Zhang ${ }^{4 *}$; Bing Zeng ${ }^{1 *}$
}

\begin{abstract}
Sorghum-sudangrass hybrid silage has poor fermentation characteristics owing to a high moisture content. Accordingly, a $3 \times 4+1$ factorial design was applied to investigate the effects of adding different types and amounts of hay (corn stalk, wheat straw, and alfalfa hay at $12.5 \mathrm{~kg} \mathrm{t}^{-1}, 25 \mathrm{~kg} \mathrm{t}^{-1}, 37.5 \mathrm{~kg} \mathrm{t}^{-1}$, and $50 \mathrm{~kg} \mathrm{t}^{-1}$ ) on the nutritive value, fermentation quality, $72 \mathrm{~h}$ dry matter digestibility, and gas dynamics in vitro to simulate the rumen fermentation of sorghum-sudangrass hybrid silage. Separated silage of sorghum-sudangrass hybrids had a high butyric acid content and a FLIEG's scores evaluation ranking of only "Fair." The addition of hay significantly improved the fermentation quality of mixed silage. With respect to hay type, adding wheat straw had the best fermentation quality, alfalfa hay had the best nutritive value, in vitro dry matter digestibility (IVDMD) $\left(662.41 \mathrm{~g} \mathrm{~kg}^{-1}\right)$, constant fractional rate (C) $\left(0.28 \mathrm{~mL} \mathrm{~h} h^{-1}\right)$, and the average gas production rate (AGPR) $\left(32.70 \mathrm{~mL} \mathrm{~h} \mathrm{~h}^{-1}\right)$ content. There were no differences in the cumulative gas production at $72 \mathrm{~h}\left(\mathrm{GP}_{72 \mathrm{~h}}\right)$, asymptotic gas production generated at a constant fractional rate (A), and lag time before gas production commenced (lag) among the three hay types. With respect to quantity, $25 \mathrm{~kg} \mathrm{t}^{-1}$ hay had the best fermentation quality, $50 \mathrm{~kg} \mathrm{t}^{-1}$ hay had the best nutritive value and highest IVDMD content $\left(662.81 \mathrm{~g} \mathrm{~kg}^{-1}\right), 37.5 \mathrm{~kg} \mathrm{t}^{-1}$ hay had the highest $\mathrm{C}(0.28 \mathrm{~mL}$ $\left.h^{-1}\right)$ and AGPR (31.48 $\left.\mathrm{mL} \mathrm{h}^{-1}\right)$ contents, $25 \mathrm{~kg} \mathrm{t}^{-1}$ hay had the highest Half time $(2.20 \mathrm{~h})$, and there were no significant differences in $\mathrm{GP}_{72 \mathrm{~h}}, \mathrm{~A}$, and lag among the four amounts. Considering both nutritive value and fermentation quality, the best mixed silage mode was $37.5 \mathrm{~kg} \mathrm{t}^{-1}$ wheat straw.
\end{abstract}

Key words: Additive. By-product. In vitro rumen fermentation. Silage quality.

\footnotetext{
1 Researcher, Department of Animal Science, Rongchang Campus of Southwest University, Chongqing, China. E-mail: lianghuan22@163.com; zbin78@163.com

2 Researcher, Guizhou Institute of Prataculture, Guiyang, China. Email: 1848266168@qq.com

3 Researcher, Dryland Farming Institute, Hebei Academy of Agricultural and Forestry Sciences, Hengshui, China. Email: 1gb2884@126.com; gsly868@163.com; yy10012_2007@163.com; zhm851@yahoo.com.cn

4 Researcher, Chongqing Academy of Animal Sciences, Chongqing, China. Email: 1075738159@qq.com; 34629646@qq.com; 474794240@qq.com

* Author for correspondence
} 


\section{Resumo}

A fim de resolver o problema da má qualidade da fermentação de silagem causada pelo alto teor de água de sorgo-sudangrass, no exame investigou a adição de diferentes tipos de feno (talos de milho, talos de trigo e feno de alfafa) e de feno $\left(12,5 \mathrm{~kg} \mathrm{t}^{-1}, 25 \mathrm{~kg} \mathrm{t}^{-1}, 37,5 \mathrm{~kg} \mathrm{t}^{-1} \mathrm{e} 50 \mathrm{~kg} \mathrm{t}^{-1}\right)$ tem qual efeito para valor nutricional do armazenamento misto silagem de sorgo-sudangrass e a qualidade de fermentação de silagem e de gases in vitro. O resultado mostra, a silagem separada de híbridos de sorgo-sudangrass tinha um conteúdo de ácido butírico elevado e um ranking de avaliação de pontuações do FLIEG apenas de "Fair". A adição de armazenamento misto de feno pode melhorar significativamente a qualidade da fermentação da ensilagem de silagem de sorgo-sudangrass, do ponto de vista dos tipos de feno adicionado, o grupo de palha de trigo apresentou a maior qualidade de fermentação da silagem, e o feno de alfafa teve o maior valor nutricional, $72 \mathrm{~h}$ de taxa de desaparecimento da matéria seca (IVDMD) do grupo feno de índica, a taxa de produção de gás (c) e a taxa de produção de gás (AGPR) chega à taxa máxima de produção de gás foram as mais altas. Não houve diferença significativa no atraso de produção de gás (lag), produção máxima teórica de gás (A), produção cumulativa de gás de três feno às $72 \mathrm{~h}\left(\mathrm{GP}_{72 \mathrm{~h}}\right)$; No ponto de vista de quantidade adicionada de feno, a qualidade de fermentação da silagem do grupo de $25 \mathrm{~kg} \mathrm{t}^{-1}$ foi a melhor, a AGPR também foi a mais longa, e o valor nutricional do grupo de $50 \mathrm{~kg} \mathrm{t}^{-1} \mathrm{e}$ a IVDMD foram os mais altos. O c e o AGPR do grupo de $37.5 \mathrm{~kg} \mathrm{t}^{-1}$ foram os maiores, adicionando feno de peso diferente não teve efeito significativo sobre $\mathrm{GP}_{72 \mathrm{~h}}$ de sorgo-sudangrass, $\mathrm{A} \mathrm{e}$ lag, Considerando a qualidade da fermentação da silagem e o valor nutricional da ração, o melhor modo de armazenamento misto foi adicionado $37.5 \mathrm{~kg} \mathrm{t}^{-1}$ de palha de trigo a sorgo-sudangrass.

Palavras-chave: Aditivos. Subprodutos. Fermentação ruminal in vitro. Qualidade de silagem.

\section{Introduction}

Sorghum-sudangrass hybrids (Sorghum bicolor $\times$ S. sudanense), which are natural hybrids of sorghum (Sorghum bicolor (L.) Moench) and sudangrass (Sorghum sudanense (Piper) Stapf) have the advantageous qualities of both parents, such as high tillering ability, strong lodging resistance, high disease resistance, and high yield, and are among the most common annual warm grass forages in the world (BECK et al., 2007; JUAN, 2010; PANG; ZHANG, 2004; YUAN et al., 2011). The forage yield is greatly influenced by the season; accordingly, it is very important to regulate forage grass by processing storage sorghum-sudangrass hybrids in the summer. Hay production from sorghum-sudangrass hybrids is difficult owing to the high moisture content and thick plant stems. However, these hybrids have a high soluble carbohydrate content and are easy to ensilage (VALENZUELA; SMITH, 2002). Therefore, ensiling is the principal methods to processing and store sorghum-sudangrass hybrids. The main problem in production of sorghumsudangrass hybrid silage is the high moisture content which leads to a bad fermentation quality of silage. Therefore, increasing studies have examined to improve fermentation quality of sorghumsudangrass hybrids silage.

Recent research on ensiling technology for sorghum-sudangrass hybrids has focused on the regulation of silage materials (AKDENIZ et al., 2012; BI et al., 2018; GUL et al., 2008; JIANG et al., 2005) and additives (DOLEZAL, 2009; HAN et al., 2015; ZHANG et al., 2010). Chopped straw is a most effective absorbent, consequently, mixing straw with grass is an accepted technique for reducing effluent loss, increasing dry matter and improving fermentation quality of mixed silage (GALLEGOS et al., 2018). Therefore, we suppose mixing straw with sorghum-sudangrass hybrids could improving the fermentation quality of mixed silage. However, mixed silage of sorghum-sudangrass hybrids has not been well explored. In this study, the nutritional characteristics of silage materials, including the nutritive value, fermentation quality, $72 \mathrm{~h}$ dry matter digestibility, and gas dynamics were examined in vitro in a simulated rumen fermentation system 
of sorghum-sudangrass hybrid silage mixed with various quantities and kinds of hay. The results of this study provide a scientific foundation for the production of high-quality sorghum-sudangrass hybrid silage.

\section{Materials and Methods}

\section{Ensiling materials}

Sorghum-sudangrass hybrids (Sorghum bicolor $\times S$. sudanense Jicao 2) were planted at the Hengshui Comprehensive Research Station Forage Industrialization Technological System of PRC $\left(37^{\circ} 44^{\prime} \mathrm{N}, 115^{\circ} 42^{\prime} \mathrm{E}, 20\right.$ m.a.s.1.) on May 15 and harvested in September 2014 (119 d) when the phenological stage of plant was in waxy ripe stage. The dry ingredients (maize straw, wheat straw, and alfalfa hay) were all provided by Hengshui Station. Sorghum-sudangrass plants were chopped using a rubbing and cutting machine, and the dry ingredients were chopped into pieces of 1-2 cm using a straw cutter. The chemical composition of ensiling materials is shown in Table 1.

Table 1. Chemical composition of ensiling materials.

\begin{tabular}{lccccc}
\hline \multicolumn{1}{c}{ Type } & $\begin{array}{c}\text { Dry matter } \\
\text { content }\end{array}$ & $\begin{array}{c}\text { Crude } \\
\text { protein }\end{array}$ & $\begin{array}{c}\text { Neutral } \\
\text { detergent fiber }\end{array}$ & $\begin{array}{c}\text { Acid } \\
\text { detergent fiber }\end{array}$ & $\begin{array}{c}\text { Water soluble } \\
\text { carbohydrate }\end{array}$ \\
\hline Sorghum-sudangrass hybrids & 170.41 & 71.92 & 617.82 & 390.41 & 39.12 \\
Wheat straw & 921.84 & 37.13 & 726.01 & 464.37 & 9.82 \\
Corn stalk & 922.28 & 58.90 & 647.69 & 366.67 & 31.22 \\
Alfalfa hay & 902.72 & 165.82 & 475.62 & 332.92 & 24.23 \\
\hline
\end{tabular}

Units: $\mathrm{g} \mathrm{kg}^{-1}$.

\section{Experimental design and ensiling}

The effects of the addition of dry ingredients on sorghum-sudangrass silage were examined during a 42 day fermentation period. Treatments were arranged in a $3 \times 4+1$ experimental design, with 3 repetitions in each treatment. The effects of 1) the dry ingredient type and 2) the quantity of dry ingredients added on sorghum-sudangrass silage were examined. Three different dry ingredients were evaluated in the ensiling process for sorghumsudangrass as follows: 1) maize straw (MS), 2) wheat straw (WS), and 3) alfalfa hay (AH). The amounts of dry ingredients were $12.5 \mathrm{~kg} \mathrm{t}^{-1}, 25 \mathrm{~kg}$ $\mathrm{t}^{-1}, 37.5 \mathrm{~kg} \mathrm{t}^{-1}$, and $50 \mathrm{~kg} \mathrm{t}^{-1}$ ( labeled 1, 2, 3, and 4 , respectively). A control treatment of sorghumsudangrass only was also included (CK).

After mixing, the mixture of each treatment was packed into three $22.82 \mathrm{~L}$ plastic pails $(20 \mathrm{~kg}$ per pail per repetition) lined with polyethylene film bags to ensure an anaerobic environment. Silage pails were opened after a 42 day fermentation period and samples were collected from each pail.

\section{Fermentation quality}

After the pails were opened, $20 \mathrm{~g}$ of the silage from each pail (each repetition) was diluted with $180 \mathrm{~mL}$ of distilled water in a conical flask, sealed with plastic wrap, maintained at $4{ }^{\circ} \mathrm{C}$ for $24 \mathrm{~h}$, and then filtered through four layers of cheesecloth and a qualitative filter paper. The filtrate was further processed with a dialyzer of $0.22 \mu \mathrm{m}$. The $\mathrm{pH}$ value of the filtrate was measured using a glass electrode $\mathrm{pH}$ meter (pHS-3C; INESA Scientific Instrument, Shanghai, China), and then the ammonia- $\mathrm{N}\left(\mathrm{NH}_{3}-\mathrm{N}\right)$ content was determined following the methods of Broderick and Kang (1980) and non-protein nitrogen (NPN) was determined following Licitra et al. (1996). The organic acid contents, including 
lactic acid (LA), acetic acid (AA), propionic acid (PA), and butyric acid (BA), were determined by high-performance liquid chromatography (HPLC) (LC-10A; Shimadzu, Tokyo, Japan) and the analytical conditions were as follows: column, Shdex RSpak KC-811S-DVB gel C (8.0 mm 930 $\mathrm{cm}$, Shimadzu); oven temperature, $50^{\circ} \mathrm{C}$; mobile phase, $3 \mathrm{mmol} \mathrm{L}^{-1} \mathrm{HClO}_{4}$; flow rate, $1.0 \mathrm{~mL} \mathrm{~min}^{-1}$; injection volume $5 \mu \mathrm{L}$; detector, SPD-M10AVP. By analysing the rate of lactic, acetic and butyric acid separately, the fermentation quality grade of mixed silage was evaluated by the FLIEG's scores method (GUO et al., 2008).

\section{Chemical composition}

A total of $200 \mathrm{~g}$ of silage from each pail was dried in $65^{\circ} \mathrm{C}$ for about $48 \mathrm{~h}$ and weighed to determine the dry matter(DM). The silage samples were ground using a cyclone mill to pass a $1-\mathrm{mm}$ screen for the measurement of total N (TN), crude protein (CP), water-soluble carbohydrates (WSC), neutral detergent fiber (NDF), and acid detergent fiber (ADF).

Kjeldahl N (i.e., TN) was analyzed following method 954.01 of the Association of Official Analytical Chemists (HELRICH, 1990). CP was calculated as Kjeldahl $\mathrm{N} \times 6.25$ (VAN SOEST et al., 1991), and WSC was analyzed by the methods of McDonald and Henderson (2010). An automatic fiber analyzer (Ankom 2000i full; Ankom Technology Corporation, Macedon, NY, USA) was used to analyze NDF and ADF (HELRICH, 1990).

\section{Rumen fluid collection}

Rumen fluid collection and in vitro batch cultures were performed at the State Key Laboratory of Animal Nutrition of China Agricultural University. Four rumen-cannulated lactating Holstein dairy cows (body weight $=510 \pm 29 \mathrm{~kg}$; days in milk = $49 \pm 8$ days; daily milk yield $=16.2 \pm 0.77 \mathrm{~kg}$ ) were used as donor animals for rumen fluid collection. The animals were housed in individual tie stalls $\left(9 \mathrm{~m}^{2}\right)$, each with separate water and feed bunk. The cows' daily feed was $4.0 \mathrm{~kg}$ alfalfa hay, 3.5 $\mathrm{kg}$ whole maize silage and $5.5 \mathrm{~kg}$ commercial concentrate consisting of $530 \mathrm{~g}$ maize meal $/ \mathrm{kg}, 140$ g soybean meal $/ \mathrm{kg}, 120 \mathrm{~g}$ distillers dried grains $/ \mathrm{kg}$, $70 \mathrm{~g}$ cotton seed meal $/ \mathrm{kg}, 40 \mathrm{~g}$ rape seed meal $/ \mathrm{kg}$, $10 \mathrm{~g}$ calcium hydrogen phosphate $\left(\mathrm{CaHPO}_{4}\right) / \mathrm{kg}, 10$ g sodium chloride $(\mathrm{NaCl}) / \mathrm{kg}, 10 \mathrm{~g}$ limestone $/ \mathrm{kg}, 10$ g sodium bicarbonate/kg and $10 \mathrm{~g}$ trace mineral/ $\mathrm{kg}$ and vitamin premix. The ration was divided equally into two portions and fed at 07:00 and 19:00 h, respectively. Rumen fluid, obtained from four animals $1 \mathrm{~h}$ before the morning feeding, was filtered through four layers of gauze and mixed in equal proportions to achieve a representative rumen fluid, held in a water-bath at $39^{\circ} \mathrm{C}$ in an atmosphere of carbon dioxide $\left(\mathrm{CO}_{2}\right)$ and used in the later in vitro batch culture. All animal care, surgical procedures, and rumen fluid collection were approved by the Institutional Animal Care and Use Committee at China Agricultural University ([2006]398).

\section{In vitro batch cultures}

The silage samples (500 mg each) were weighed and added to a total of 65 glass bottles (five bottles per treatment) with butyl rubber stoppers. Fresh buffer solution ( $\mathrm{pH}$ 6.8) was prepared following the methods of Menke and Steingass (1988). Under a stream of nitrogen gas, each bottle was inoculated with $50 \mathrm{~mL}$ of the buffer solution followed by 25 $\mathrm{mL}$ of rumen fluids (filtered through four layers of cheesecloth). Anaerobic $\mathrm{N}_{2}$ was purged into each bottle for $5 \mathrm{~s}$ to remove headspace air, and then each bottle was sealed with a butyl rubber stopper and a screw cap. All bottles were individually connected with medical plastic infusion pipes to the gas inlets of an automated trace gas recording instrument (AGRS-III, China Agricultural University, Beijing, China) to continuously record gas production (ZHANG; YANG, 2011). Three fermentations 
without the substrate were included as blanks. All bottles were incubated at $39^{\circ} \mathrm{C}$ for $72 \mathrm{~h}$.

After $72 \mathrm{~h}$ of incubation for each bottle, the cumulative gas production volumes against incubation time were exported into a Microsoft Excel datasheet from the AGRS-III. The supernatants in each bottle were decanted and the pellets were dried at $65^{\circ} \mathrm{C}$ to a constant weight for determination of the residual DM. IVDMD was calculated as the DM loss, estimated as the difference between the initial and residual DM, corrected by blanks.

\section{Calculation and statistical analysis}

The cumulative gas production (GPt, $\mathrm{mL}$ $\left.\mathrm{g}^{-1} \mathrm{DM}\right)$ at time $(\mathrm{t})$ was fitted to an exponential model (Eqn (1)) by an iterative regression analysis (TOMPSETT, 2000) using the nonlinear procedure of SAS for Windows as follows:

$$
\mathrm{GPt}=[1-\mathrm{e}-\mathrm{c} \times(\mathrm{t}-\mathrm{lag})] \times \mathrm{A} \text { 。 }
$$

where A represents the asymptotic GP generated at a constant fractional rate (c) per unit time (h); $t$ is the gas recording time $(\mathrm{h})$, and lag represents the lag time (h) before GP commenced.

Following the methods of Garciamartinez et al. (2005), the average gas production rate (AGPR, $\mathrm{mL} / \mathrm{h}$ ) between the start of the incubation period and the time at which the cumulative gas production was half of its asymptotic value was calculated as follows:

$$
\mathrm{AGPR}=\mathrm{A} \times \mathrm{c} /(\log 2+\mathrm{c} \times \operatorname{lag}) .
$$

The chemical composition results and fermentation characteristics are expressed as means \pm S.E.M. Differences between groups were determined by one-way analysis of variance and post-hoc comparisons (LSD; least significant difference) using a commercial software package (SPSS version 20.0, SPSS Inc., Chicago, IL, USA). Differences were considered significant at $\mathrm{P}<0.05$.

\section{Results}

Chemical composition of mixed silage of sorghumsudangrass hybrids

As shown in Table 2, there were interactions between hay type and adding amount in DM and $\mathrm{CP}$ contents $(\mathrm{P}<0.05)$. The best combination in $\mathrm{DM}$ and $\mathrm{CP}$ contents was adding $50 \mathrm{~kg} \mathrm{t}^{-1}$ alfalfa hay. There was no interaction between hay type and adding amount in NDF, ADF and WSC contents (P $>0.05)$.

With respect to hay type, there were no differences in DM, ADF and WSC contents among the three dry ingredients groups $(\mathrm{P}>0.05)$. The $\mathrm{CP}$ content was significantly higher for sorghum-sudangrass hybrid silage mixed with alfalfa hay $(\mathrm{AH})$ than mixed with maize stalk (MS) or wheat straw (WS) $(\mathrm{P}<0.05)$. The NDF content was significantly higher in the CS group than in the AH and WS groups $(\mathrm{P}<0.05)$. These results indicated that the nutrient content of mixed silage was highest for alfalfa hay, followed closely by wheat straw. 


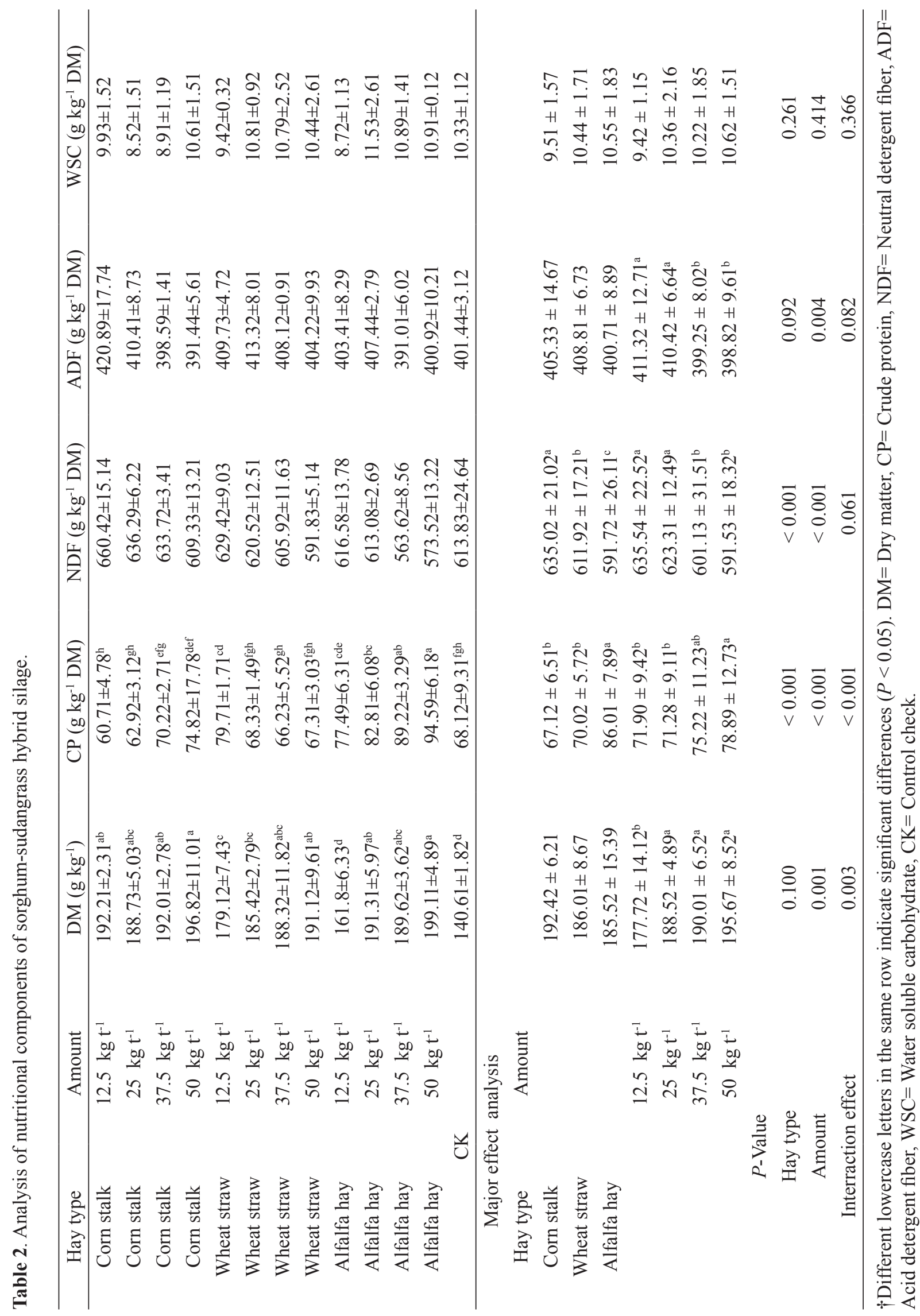


With respect to the amount, the DM and CP content of mixed silage increased and the NDF and ADF content decreased as the amount of dry ingredients increased. The DM content in the 12.5 $\mathrm{kg} \mathrm{t}^{-1}$ group was significantly lower than those of the other three groups $(\mathrm{P}<0.05)$. The $\mathrm{CP}$ content in the $50 \mathrm{~kg} \mathrm{t}^{-1}$ group was significantly higher than those in the $12.5 \mathrm{~kg} \mathrm{t}^{-1}$ and $25 \mathrm{~kg} \mathrm{t}^{-1}$ groups $(\mathrm{P}<0.05)$. The NDF and ADF contents of the $50 \mathrm{~kg} \mathrm{t}^{-1}$ group were significantly lower than those for the $12.5 \mathrm{~kg}$ $\mathrm{t}^{-1}$ and $25 \mathrm{~kg} \mathrm{t}^{-1}$ groups $(\mathrm{P}<0.05)$. There were no differences in WSC content among the four groups. The nutrient contents in the $37.5 \mathrm{~kg} \mathrm{t}^{-1}$ and $50 \mathrm{~kg} \mathrm{t}^{-1}$ groups were significantly higher than those in the $12.5 \mathrm{~kg} \mathrm{t}^{-1}$ and $25 \mathrm{~kg} \mathrm{t}^{-1}$ groups $(\mathrm{P}<0.05)$, and there was no difference between the $37.5 \mathrm{~kg} \mathrm{t}^{-1}$ and $50 \mathrm{~kg}$ $\mathrm{t}^{-1}$ groups.

Fermentation quality of mixed silage of sorghumsudangrass hybrids

As shown in Table 3, there was no interaction between hay type and adding amount in $\mathrm{pH}, \mathrm{AN} /$ TN, LA, PA, AA and BA contents $(\mathrm{P}>0.05)$.

With respect to hay type, there were no differences in PA and BA contents among the three dry ingredients groups $(P>0.05)$. The LA content of the wheat straw group was significantly higher than that in the corn stalk group $(\mathrm{P}<0.05)$. The $\mathrm{pH}$ values and $\mathrm{AA}$ content in the wheat straw group were significantly lower than those in the corn stalk group $(\mathrm{P}<0.05)$. The AN/TN content of the corn stalk group was significantly higher than those of the other two groups $(\mathrm{P}<0.05)$. Overall, the fermentation quality of mixed silage was best for wheat straw and worst for corn stalk.

In the terms the amount added, the AA content of mixed silage decreased as the amount of dry ingredients increased; it was significantly higher in the $12.5 \mathrm{~kg} \mathrm{t}^{-1}$ group than in the $37.5 \mathrm{~kg} \mathrm{t}^{-1}$ and $50 \mathrm{~kg} \mathrm{t}^{-1}$ groups $(\mathrm{P}<0.05)$. The LA content was significantly higher in this group than in the 12.5 $\mathrm{kg} \mathrm{t}^{-1}$ group $(\mathrm{P}<0.05)$. The $\mathrm{pH}$ value in the 12.5 $\mathrm{kg} \mathrm{t}^{-1}$ group was significantly higher than those in the other three groups $(\mathrm{P}<0.05)$. There were no differences in PA, BA, and AN/TN contents among the four groups $(\mathrm{P}>0.05)$, but BA was not detected in the $25 \mathrm{~kg} \mathrm{t}^{-1}$ and $37.5 \mathrm{~kg} \mathrm{t}^{-1}$ groups, which had a better performance. Therefore, sorghum-sudangrass hybrid silage supplemented with $25 \mathrm{~kg} \mathrm{t}^{-1}$ dry ingredients had the best performance with respect to fermentation quality, followed closely by the 37.5 $\mathrm{kg} \mathrm{t}^{-1}$ group. The worst performed was observed for the $12.5 \mathrm{~kg} \mathrm{t}^{-1}$ group.

As summarized in Table 4, the FLIEG's scores for separate silage of sorghum-sudangrass hybrids were only classified as "Fair," indicating bad performance. All other FLIEG's evaluations for treatment groups were classified as "Excellent" or "Well." 


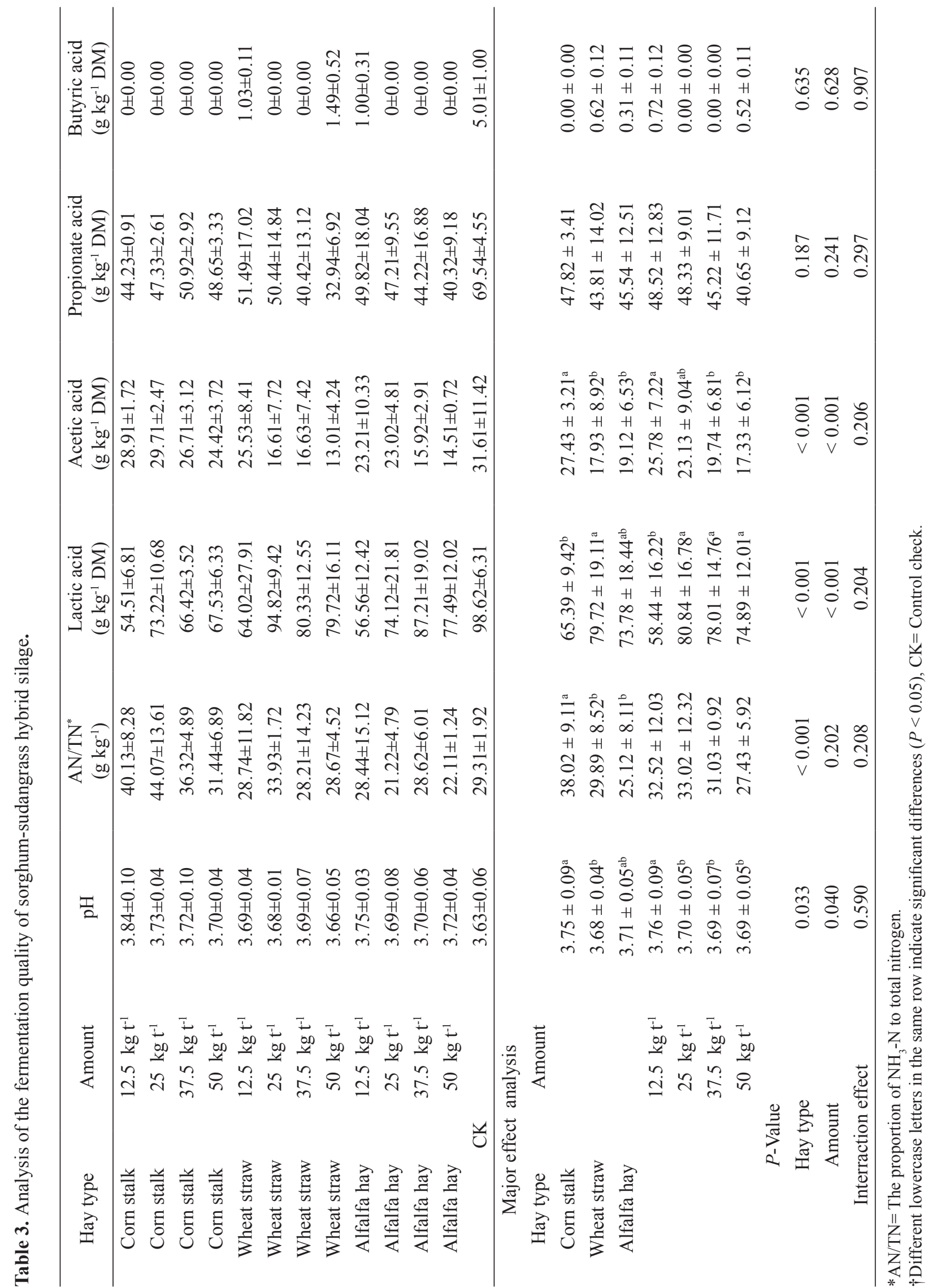


Table 4. FLIEG's scores of silage.

\begin{tabular}{cccccc}
\hline Groups & Lactic acid score & Acetic acid score & Butyric acid score & Total score & Rank \\
\hline MS1 & 9 & 16 & 50 & 75 & Well \\
MS2 & 12 & 18 & 50 & 80 & Well \\
MS3 & 11 & 18 & 50 & 79 & Well \\
MS4 & 12 & 19 & 50 & 81 & Excellent \\
WS1 & 10 & 18 & 50 & 78 & Well \\
WS2 & 17 & 20 & 50 & 87 & Excellent \\
WS3 & 17 & 20 & 50 & 87 & Excellent \\
WS4 & 19 & 20 & 50 & 89 & Excellent \\
AH1 & 10 & 19 & 50 & 79 & Well \\
AH2 & 13 & 19 & 50 & 82 & Excellent \\
AH3 & 17 & 20 & 50 & 87 & Excellent \\
AH4 & 17 & 20 & 50 & 87 & Excellent \\
CK & 12 & 18 & 30 & 60 & Fair \\
\hline
\end{tabular}

$\dagger 1)$ MS, WS and AH correspond to maize straw, wheat straw, and alfalfa hay, respectively. The number 1, 2, 3 and 4 correspond to the adding amount of $12.5 \mathrm{~kg} \mathrm{t}^{-1}, 25 \mathrm{~kg} \mathrm{t}^{-1}, 37.5 \mathrm{~kg} \mathrm{t}^{-1}$, and $50 \mathrm{~kg} \mathrm{t}^{-1}$, respectively, CK= Control check.

IVDMD, kinetic parameters of gas production of sorghum-sudangrass hybrid silage

As shown in Table 5, there was no interaction between hay type and adding amount in IVDMD, $\mathrm{GP}_{72 \mathrm{~h}}, \mathrm{~A}, \mathrm{C}, \mathrm{Lag}$, Half time and AGPR contents (P $>0.05)$.

With respect to hay type, the IVDMD, C, and AGPR of the AH group were significantly higher than in the other two groups $(\mathrm{P}<0.05)$. The half time of the AH group was significantly shorter than in the other two groups $(\mathrm{P}<0.05)$. There were no differences in $\mathrm{GP}_{72 \mathrm{~h}}, \mathrm{~A}$, and lag among the three groups $(\mathrm{P}>0.05)$.
In terms of the amount added, the IVDMD content was significantly higher in the $50 \mathrm{~kg} \mathrm{t}^{-1}$ group than in the $12.5 \mathrm{~kg} \mathrm{t}^{-1}$ group $(\mathrm{P}<0.05)$. The $\mathrm{C}$ and AGPR contents of the $37.5 \mathrm{~kg} \mathrm{t}^{-1}$ group were significantly higher than those of the $25 \mathrm{~kg} \mathrm{t}^{-1}$ groups $(\mathrm{P}<0.05)$. The half time of the $25 \mathrm{~kg} \mathrm{t}^{-1}$ group was significantly longer than those of the $12.5 \mathrm{~kg} \mathrm{t}^{-1}$ and $37.5 \mathrm{~kg} \mathrm{t}^{-1}$ groups $(\mathrm{P}<0.05)$. There were no differences in $\mathrm{GP}_{72 \mathrm{~h}}, \mathrm{~A}$, and lag among the four groups $(\mathrm{P}>0.05)$. 


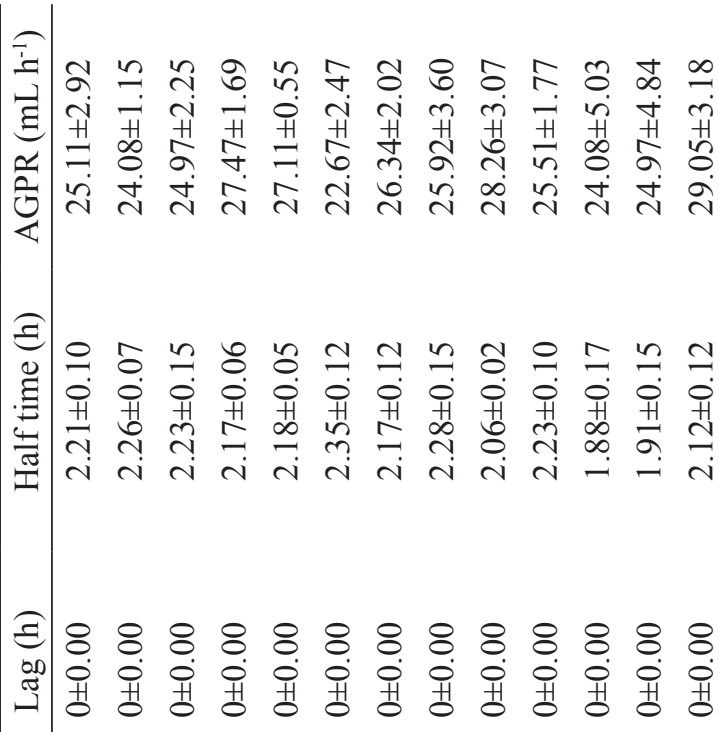

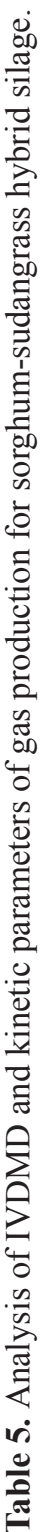

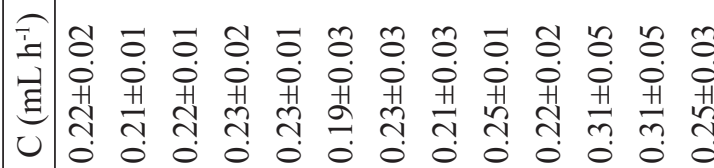

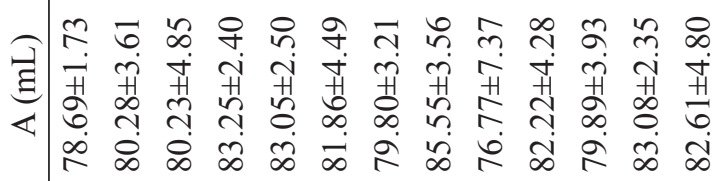

(5)

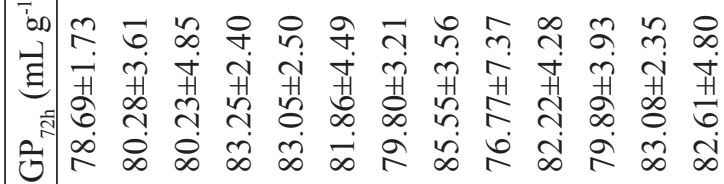

(5)

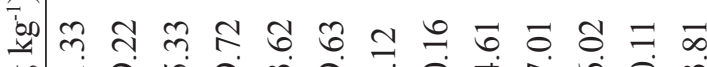

0 的守

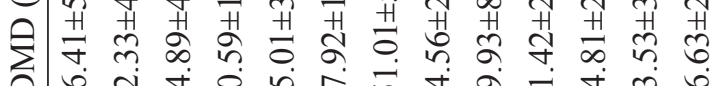

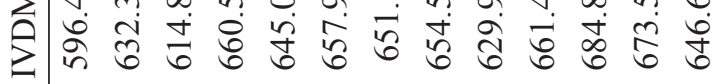

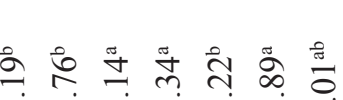

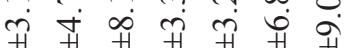

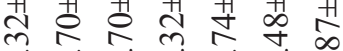
ते तं क्ते ले

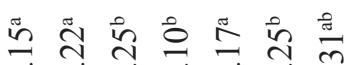

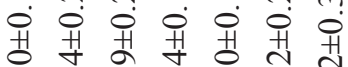
๙ָ

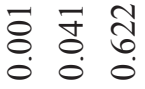

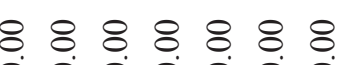

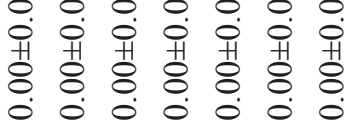

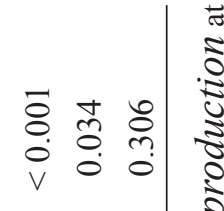

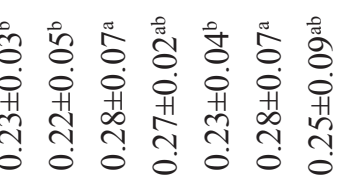

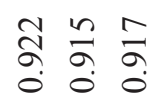

$\infty$ ले + t.

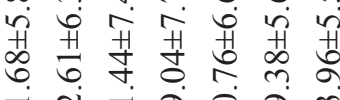

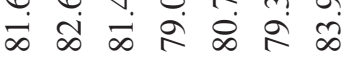

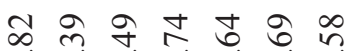

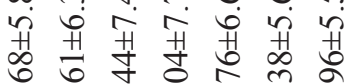

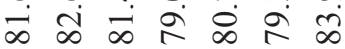

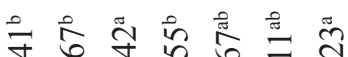
莳 ¿ै สู่

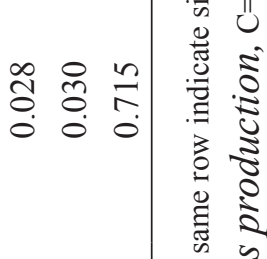

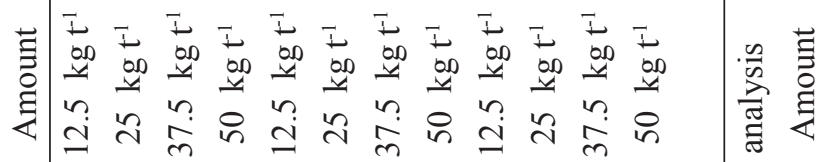

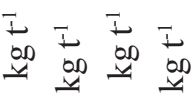

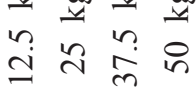

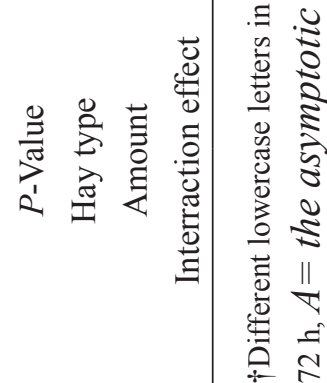




\section{Discussion}

Separate silage of sorghum-sudangrass hybrids

The moisture content of sorghum-sudangrass hybrids is very high, providing a favorable environment for the proliferation of Clostridium spp. (WEI; WANG, 2010). Butyric acid secreted by Clostridium spp. has a bad odor and decreases the fermentation quality of silage (BORBA et al., 2012). In the present study, the FLIEG'S score evaluation ranking for separate silage was only "Fair" owing to a higher content of butyric acid, which means that sorghum-sudangrass hybrids could be ensiled alone, but the fermentation quality was not good. This result was consistent with those of $\mathrm{Ji}$ et al. (2012). All mixed silage of sorghum-sudangrass hybrids had a good fermentation quality.

\section{Chemical composition and fermentation quality of mixed silage}

The proportion of $\mathrm{NH}_{3}-\mathrm{N}$ to $\mathrm{TN}$, and LA and VFA contents are important indicators of the fermentation quality of silage (SELMEROLSEN, 2010). The $\mathrm{NH}_{3}-\mathrm{N} / \mathrm{TN}$ content not only reflects the degree of proteolysis during silage fermentation, but also affects the utilization efficiency of $\mathrm{N}$ in the rumen (TUULOS et al., 2015). Higher $\mathrm{NH}_{3}-\mathrm{N}$ production in silage is associated with a lower silage fermentation quality. In this study, the $\mathrm{NH}_{3}-\mathrm{N} / \mathrm{TN}$ content of sorghum-sudangrass hybrid silage was lower when mixed with AH or WS than MS. This may be explained by the low $\mathrm{pH}$ value of the silage mixed with AH or WS. A low $\mathrm{pH}$ can inhibit the protease activity and thus decrease the $\mathrm{NH}_{3}-\mathrm{N} / \mathrm{TN}$ content (CUSSEN et al., 2010). The $\mathrm{NH}_{3}-\mathrm{N} / \mathrm{TN}, \mathrm{AA}$, and PA contents of mixed silage gradually decreased as the amount of dry ingredients increased. It is possible that the DM content and nutritive value of sorghum-sudangrass hybrid silage were significantly improved after mixing with dry ingredients, which could promote the activity of LAB and lignocellulose degradation enzymes to improve the fermentation quality (TIAN et al., 2015).

\section{IVDMD, kinetic parameters of gas production of} mixed silage

Fodder degradation in the rumen is the consequence of the decomposition and utilization of nutrients in fodder by rumen microorganisms (ZHANG et al., 2013). In the present study, the IVDMD content of mixed silage decreased according to AH group $>$ WS group $>$ MS group and $50 \mathrm{~kg} \mathrm{t}^{-1}>37.5 \mathrm{~kg} \mathrm{t}^{-1}>25 \mathrm{~kg} \mathrm{t}^{-1}>12.5 \mathrm{~kg}$ $\mathrm{t}^{-1}$. There are two potential explanations for the high IVDMD content of silage mixed with AH. First, alfalfa is a legume, and sorghum-sudangrass hybrids, maize, and wheat are graminaceous crops. From the perspective of complementary functions of nutrients, those in the combination of grass and legume forages are more favorable than those for a single kind of forage (YANG et al., 2008). The sorghum-sudangrass hybrid silage mixed with $\mathrm{AH}$ had balanced nutrients, which can accelerate the growth of rumen microorganisms and improve the fermentation potential of protein and water-soluble carbohydrates (PRASAD et al., 2010), thereby improving the IVDMD content. Similar results have been reported in a study by Cui et al. (2012). In addition, the low ADF content of AH may explain the high IVDMD content.

Carbohydrates are the main source of in vitro gas production of forages. Although protein can also produce gas during fermentation, it is not comparable in volume to carbohydrate fermentation (CONE; AHVAN, 1999). In the present study, there were no differences in $\mathrm{GP}_{72 \mathrm{~h}}$ and A contents of mixed silage among the three dry ingredient groups. This can probably be attributed to the inferior fermentation gas contribution of protein relative to carbohydrates. The $\mathrm{C}$ and AGPR of silage mixed with $\mathrm{AH}$ were highest among the three dry ingredients, possibly reflecting the high contents of 
cellulose, hemicellulose, and lignin in wheat straw and maize straw, reducing the gas generation rate of the fermentation substrate. The $\mathrm{C}$ and AGPR contents of mixed silage in the $37.5 \mathrm{~kg} \mathrm{t}^{-1}$ group were highest and significantly higher than those in the $25 \mathrm{~kg} \mathrm{t}^{-1}$ group, suggesting that adding $37.5 \mathrm{~kg}$ $\mathrm{t}^{-1} \mathrm{AH}$ facilitated the balance of energy and protein in the fermentation substrate.

The lag is significantly positively correlated with the NDF and ADF contents and significantly negatively correlated with the $\mathrm{CP}$ and neutral detergent soluble (NDS) contents of the fermentation substrate (SUN et al., 2014). In the present study, the lag was zero in all treatments; it is possible that the very high content of WSC in sorghumsudangrass hybrids provides ample nutrients for rapid degradation by rumen microorganisms.

\section{Conclusions}

Sorghum-sudangrass hybrids can be ensiled alone, but have a high butyric acid content and a low fermentation quality. The addition of various hay types and amounts could significantly improve the fermentation quality of mixed silage. Synthetically considering the nutritive value and fermentation quality, $50 \mathrm{~kg} \mathrm{t}^{-1}$ alfalfa hay had the highest IVDMD content, $37.5 \mathrm{~kg} \mathrm{t}^{-1}$ alfalfa hay had the highest gas production rate, and $50 \mathrm{~kg} \mathrm{t}^{-1}$ wheat straw had the highest $\mathrm{GP}_{72 \mathrm{~h}}$ and $\mathrm{A}$, the best mixed silage mode was the addition of $37.5 \mathrm{~kg} \mathrm{t}^{-1}$ wheat straw. These results indicate that the addition of $37.5 \mathrm{~kg} \mathrm{t}^{-1}$ wheat straw could not only improve the fermentation quality of Sorghum-sudangrass hybrids silage, but also maximize the crop value and minimize agricultural losses.

\section{Acknowledgments}

This research is supported by the National Science and Technology Support Project "Grassland system pest control green technology research and demonstration" (2014BAD23B03-3), Chongqing Herbivorous Livestock Industrial Technology System Forage and Feed nutrition Laboratory Construction Project, China Agriculture Research System Construction Project (CARS35-24), Chongqing University Innovation Team Building Plan Projects in 2016 "Beef cattle modern production technology (No: CXTDG201602003), Beef Cattle Engineering and Technology Research Center of Chongqing and Chongqing Technology Innovation and Application Demonstration Project "Development, utilization and demonstration of high-quality local forage resources" (cstc2018jsckmszdx0060).

\section{References}

AKDENIZ, H.; KARSLI, M. A.; YILMAZ, I. Effects of harvesting different sorghum-sudan grass varieties as hay or silage on chemical composition and digestible dry matter yield. Journal of Animal \& Veterinary Advances, Dubai, v. 4, n. 6, p. 610-614, 2012.

BECK, P. A.; HUTCHISON, S.; GUNTER, S. A.; LOSI, T. C.; STEWART, C. B.; CAPPS, P. K.; PHILLIPS, J. M. Chemical composition and in situ dry matter and fiber disappearance of sorghum x Sudangrass hybrids. Journal of Animal Science, Champaign, v. 85, n. 2, p. 545-55, 2007.

BI, J. W.; XUAN, J. J.; YU, J. H.; WANG, L. K.; HU, Z. Z.; REN, Q. C. Effect of time on carbohydrate contents of whole maize and sorghum sudanense (Piper) stapf silage. Journal of Anhui Science and Technology University, Chuzhou, v. 32, n. 2, p. 26-31, 2018.

BORBA, L. F. P.; FERREIRA, M. D. A.; GUIM, A.; TABOSA, J. N.; GOMES, L. H. D. S.; SANTOS, V. L. F. D. Nutritive value of diferents silage sorghum (Sorghum bicolor L. Moench) cultivares. Acta Scientiarum. Animal Sciences, Maringá, v. 34, n. 2, p. 123-129, 2012.

BRODERICK, G. A.; KANG, J. H. Automated simultaneous determination of ammonia and total amino acids in ruminal fluid and in vitro media. Journal of Dairy Science, Champaign, v. 63, n. 1, p. 63-64, 1980.

CONE, J. W.; AHVAN, G. Influence of protein fermentation on gas production profiles. Animal Feed Science \& Technology, Amsterdam, v. 76, n. 3, p. 251264, 1999. 
CUI, Z. H.; HAO, L. Z.; LIU, S. J.; CHAI, S. T.; ZHAO, Y. P.; ZHANG, X. W. Evaluation of the fermentation characteristics of mixed oat green hay and native pastures in the Qinghai plateau using an in vitro gas production technique. Acta Prataculturae Sinica, Lanzhou, v. 60, n. 12, p. 2257-2262, 2012.

CUSSEN, R. F.; MERRY, R. J.; WILLIAMS, A. P.; TWEED, J. K. S. The effect of additives on the ensilage of forage of differing perennial ryegrass and white clover content. Grass and Forage Science, Malden, v. 50, n. 3, p. 249-258, 2010.

DOLEZAL, P. S. Quality of silage from brown midrib sorghum x sudangrass forage. Animal Welfare, Ethology and Housing Systems, San Diego, v. 4, n. 1, p. 98-102, 2009.

GALLEGOS, D.; WEDWITSCHKA, H.; MOELLER, L.; WEINRICH, S.; ZEHNSDORF, A.; NELLES, M.; STINNER, W. Mixed silage of Elodea, and wheat straw as a substrate for energy production in anaerobic digestion plants. Energy Sustainability and Society, Edinburgh, v. 8, n, 1, p. 7-8, 2018.

GARCIAMARTINEZ, R.; RANILLA, M. J.; TEJIDO, M. L.; CARRO, M. D. Effects of disodium fumarate on in vitro rumen microbial growth, methane production and fermentation of diets differing in their forage: concentrate ratio. British Journal of Nutrition, Cambridge, v. 94, n, 1, p. 71-77, 2005.

GUL, I.; DEMIREL, R.; KILICALP, N.; SUMERLI, M.; KILIC, H. Effect of crop maturity stages on yield, silage chemical composition and in vivo digestibilities of the maize, sorghum and sorghum-sudangrass hybrids grown in semi-Arid conditions. Journal of Animal and Veterinary Advances, Dubai, v. 7, n. 1, p. 1021-1028, 2008.

GUO, X. S.; DING, W. R.; YU, Z. The evaluation system of fermentation quality of ensiled forage and its improvement. Chinese Journal of Grassland, Hohhot, v. 30, n. 4, p. 100-106, 2008.

HAN, L. Y.; LI, J.; NA, R. S.; YU, Z.; ZHOU, H. Effect of two additives on the fermentation, in vitro digestibility and aerobic security of Sorghum-sudangrass hybrid silages. Grass and Forage Science, Malden, v. 70, n. 1, p. 185-194, 2015.

HELRICH, K. C. Official methods of Analysis of the $A O A C$. Gaithersburg: AOAC International, v. 2, p. 2333, 1990.

JI, X.; YU, Z.; BAI, C. S.; XUE, G.; GUO, Y. P. Effect of additives on quality of sorghum-sudangrass hybrids silage. Acta Agrestia Sinica, Beijing, v. 20, n. 1, p. 571$575,2012$.
JIANG, Y.; WANG, C.; LI, Z. Effect of several cutting heights on the yield, quality and silage effect of Gaodancao. Journal of Henan Agricultural Sciences, Zhengzhou, v. 3, n. 1, p. 78-79, 2005.

JUAN, H. Effect of nitrogen application rate on forage productivity and utilization of soil mineral nitrogen in Sorghum hybrid sudangrass. Yangzhou: Yangzhou University, p. 24-38, 2010.

LICITRA, G.; HERNANDEZ, T. M.; SOEST, P. J. V. Standardization of procedures for nitrogen fraction on ruminant feeds. Animal Feed Science and Technology, Amsterdam, v. 57, n. 4, p. 347-358, 1996.

MCDONALD, P.; HENDERSON, A. R. Determination of water-soluble carbohydrates in grass. Journal of the Science of Food Agriculture, Chichester, v. 15, n. 6, p. 395-398, 2010.

MENKE, K. H.; STEINGASS, H. Estimation of the energetic feed value obtained by chemical analysis and in vitro gas production using rumen fluid. Animal Research Development, Stuttgart, v. 28, n. 1, p. 7-55, 1988.

PANG, L.; ZHANG, J. Biological characteristics of sudan grass and sorghum-sudan hybrid. Southwest China Journal of Agricultural Sciences, Chongqing, v. 17, n. 1, p. 160-163, 2004.

PRASAD, C. S.; WOOD, C. D.; SAMPATH, K. T. Use of in-vitro gas production to evaluate rumen fermentation of untreated and urea treated finger millet straw (Eleusine coracana) supplemented with different levels of concentrate. Journal of Science of Food and Agriculture, Chichester, v. 65, n. 4, p. 457-464, 2010.

SELMEROLSEN, I. Enzymes as silage additives for grass-clover mixtures. Grass and Forage Science, Malden, v. 49, n. 3, p. 305-315, 2010.

SUN, G. Q.; LU, Y. Y.; ZHANG, J. J. A study on the associative effect of whole corn silage-peanut vine and Leymus chinensis by rumen fermentation in vitro. Acta Prataculturae Sinica, Lanzhou, v. 23, n. 3, p. 224-231, 2014.

TIAN, J. P.; YU, Y. D.; YU, Z.; SHAO, T.; NA, R. S.; ZHAO, M. M. Effects of lactic acid bacteria inoculants and cellulase on fermentation quality and in vitro digestibility of Leymus chinensis silage. Grassland Science, Miyazaki, v. 60, n. 4, p. 199-205, 2015.

TOMPSETT, S. L. Estimating the extent of degradation of ruminant feeds from a description of their gas production profiles observed in vitro: derivation of models and other mathematical considerations. British Journal of Nutrition, Cambridge, v. 83, n. 2, p. 143-150, 2000. 
TUULOS, A.; TURAKAINEN, M.; JAAKKOLA, S.; KLEEMOLA, J.; MAKELA, P. S. A. Forage and seed yield of winter turnip rape established as a mixed crop with cereals. Journal of Agricultural Science, Cambridge, v. 153, n. 2, p. 222-235, 2015.

VALENZUELA, H.; SMITH, J. Sorghum-sudangrass hybrids (Green Manure Crops). Sustainable Agriculture, Binghanton, v. 10, n. 1, p. 1-4, 2002.

VAN SOEST, P. J.; ROBERTSON, J. B.; LEWIS, B. A. Methods for dietary fiber, neutral detergent fiber, and nonstarch polysaccharides in relation to animal nutrition. Journal of Dairy Science, Champaign, v. 74, n. 10, p. 8397, 1991.

WEI, C. Q.; WANG, M. J. The silage making and nutritive variation of Trifolium ambiguum. Pratacultural Science, Beijing, v. 27, n, 2, p. 134-138, 2010.

YANG, F. L.; DING, X. Z.; SHI, H. S.; HUANG, X. D.; LONG, R. J. Study on in vitro fermentation characteristics of alfalfa hay mixed with straw and their combined utilization. Pratacultural Science, Beijing, v. 25, n. 3, p. 61-67, 2008.
YUAN, L.; XIE, N.; ZHAO, H. M.; LIU, G. B.; XIE, J. $\mathrm{X}$. Analysis on change pattern of the vegetative growth and forage quality of sorghum bicolor $\times$ S. sudanense. Acta Agrestia Sinica, Beijing, v. 19, n. 1, p. 813-819, 2011.

ZHANG, D. F.; YANG, H. J. In vitro ruminal methanogenesis of a hay-rich substrate in response to different combination supplements of nitrocompounds; pyromellitic diimide and 2-bromoethanesulphonate. Animal Feed Science and Technology, Amsterdam, v. 163, n. 2, p. 20-32, 2011.

ZHANG, S. P.; CHEN, Z.; LIU, D. L. Effect of different additives on the perfermance and in vitro degradation characteristics of Sorghumsudan grass hybrids. Chinese Journal of Animal Science, Beijing, v. 46, n. 1, p. 65-69, 2010.

ZHANG, X.; LIN, L.; MENG, Q.; ZHAO, L.; REN, L. Effects of calcium propionate on in vitro ruminal gas production, fermentation parameters and dry matter degradation rate of substrate with high concentrate. Chinese Journal of Animal Nutrition, Beijing, v. 25, n. 12, p. 2906-2912, 2013. 